OPEN ACCESS

Edited by: Barbara Bosio University of Genoa, Italy

Reviewed by Elisabetta Arato

University of Genoa, Italy

Timothy A. Barckholtz, ExxonMobil, United States

*Correspondence: Michel Cassir michel.cassir@chimieparistech.psl.eu

Specialty section: This article was submitted to Fuel Cells,

a section of the journal Frontiers in Energy Research

Received: 09 February 2021 Accepted: 22 March 2021

Published: 29 April 2021

Citation:

Gürbüz E, Grépin E, Ringuedé A, Lair V and Cassir M (2021)

Significance of Molten Hydroxides With or Without Molten Carbonates in High-Temperature Electrochemical

Devices.

Front. Energy Res. 9:666165. doi: 10.3389/fenrg.2021.666165

\section{Significance of Molten Hydroxides With or Without Molten Carbonates in High-Temperature Electrochemical Devices}

\author{
Ersan Gürbüz, Elisa Grépin, Armelle Ringuedé, Virginie Lair and Michel Cassir* \\ Chimie Paristech-CNRS, Institut de Recherche de Chimie de Paris, PSL Research University, Paris, France
}

Due to their low melting point and high conductivity molten hydroxides are interesting electrolytes, or additive to other molten electrolytes for high-temperature electrochemical devices. There is nowadays a revival of such reactive media, first of all for their significant role in the electrode mechanisms in molten carbonate fuel cells (MCFCs) and the reverse co-electrolysis of water and carbon dioxide process, but also in different applications, among which direct carbon fuel cells (DCFCs), hybrid carbonate/oxide fuel cells. This overview shows the properties and interest of molten hydroxides and their use in relevant energy devices, pointing out their direct use as electrolytic media or as key species in complex kinetic processes. A thorough understanding of their behavior should allow improving and optimizing significantly fuel cells, electrolyzers, and probably also $\mathrm{CO}_{2}$ capture and valorization.

Keywords: molten hydroxides, molten carbonates, MCFC, MCEC, DCFC

\section{INTRODUCTION}

Molten salts are of great interest in electrochemistry, particularly in the field of fuel cells and electrolyzers. Indeed, the reaction kinetics are favored by the high-temperature operation. Molten carbonate fuel cells (MCFC) are now a mature technology with about 40 to $50,000 \mathrm{~h}$ of operation, electric efficiencies of about $50 \%$ and powers up to $60 \mathrm{MW}$. Due to the properties of molten carbonates and the high $\mathrm{CO}_{2}$ solubility in this medium (Meléndez-Ceballos et al., 2020), MCFCs can also be used for carbon capture and storage (CCS) applications, such as $\mathrm{CO}_{2}$ concentration and separation (Intergovernmental Panel on Climate Change, 2005; Wade et al., 2007; Cassir et al., 2012; McPhail et al., 2015; Fuel Cell Energy, 2017, 2019). This device can also be operated reversibly, as a molten carbonate electrolysis cell or MCEC (Hu et al., 2014; Perez-Trujillo et al., 2018; Meskine et al., 2020).

Within molten salts, molten hydroxides are specifically intriguing, as they feature notable advantages compared to other salts and namely molten carbonates: possibility of working at lower temperatures, higher conductivity, and higher activity of carbon (Zecevic et al., 2004).

As with molten carbonates, the concept of oxoacidity applies for molten hydroxides. Indeed, they are also subject to a similar auto-dissociation equilibrium, where $\mathrm{H}_{2} \mathrm{O}$ is the conjugated oxoacid:

$$
2 \mathrm{OH}^{-} \leftrightarrow \mathrm{O}^{2-}+\mathrm{H}_{2} \mathrm{O}
$$


Such equilibria have already been studied from a fundamental point of view, notably by Goret (1966) and Eluard (1970) who focused their interest on establishing the basic equilibria in molten alkali hydroxides, as well as potential-oxoacidity diagrams and analyzed the behavior of some metals in this medium.

This review will focus on the role of molten hydroxides in several fuel cell systems and specifically the MCFC, stressing out the promising applications related to such media, as pure phases or additives.

\section{OVERVIEW ON MOLTEN HYDROXIDES}

Molten hydroxides are a specific type of molten salt that generally melts at a lower temperature than most others (chlorides, carbonates, and fluorides) (Janz et al., 1968). As an example, single molten alkali hydroxides melt at around $350^{\circ} \mathrm{C}$ and the melting temperature can be lowered even further by forming eutectic mixtures (Janz et al., 1968). They have been used to obtain sodium or potassium by electrolysis of molten $\mathrm{NaOH}$ or $\mathrm{KOH}$ by Davy in 1807, which has paved the way for some industrial processes such as the Castner process (production of sodium metal by electrolysis of molten hydroxides). Besides, alkali fusion methods, dissolving and extracting valuables compounds from ceramics or glasses, and synthesis of various oxides also feature molten hydroxides (Lee and Holland, 1991; Mori, 2003; Minakawa et al., 2008; Gunnarson, 2009; Wang et al., 2009, 2012; Xu et al., 2011; Lusiola et al., 2012). As will be detailed in this paper, molten hydroxides have also been considered as high-temperature electrolytes for energy and specifically fuel cell applications. Due to their interesting applications, these salts have been studied from a fundamental and experimental approach, whether for their chemical, catalytic (Williams et al., 1956; Janz et al., 1968; Dauby et al., 1979; Claes and Gilbert, 1985; Saïb et al., 1998; Lapshin et al., 2004; Moneuse et al., 2009; Sang et al., 2015) or electrochemical (Goret, 1966; Eluard, 1970; Zecchin et al., 1974; Saïb et al., 1998; Claes et al., 1999; Miles, 2003; Sher et al., 2020) properties. First, it should be noted that molten hydroxides, although with low melting points, present a high conductivity (Janz et al., 1968). $\mathrm{NaOH}$ at $427^{\circ} \mathrm{C}$ has twice the conductivity of $\mathrm{NaNO}_{3}$ at the same temperature, and has around the same conductivity as $\mathrm{Na}_{2} \mathrm{CO}_{3}$ at a much higher temperature of $907^{\circ} \mathrm{C}$ (Janz et al., 1968). Table 1 below features some general data on common molten alkali hydroxides.

Redox reactivity in these molten salts go through the oxide anion (instead of the proton for aqueous systems). In order to analyze reactions, the oxoacidity concept introduced by Lux and Flood is used: an acid (oxoacid) is a species that is an oxide acceptor and a base (oxobase) an oxide donor. Thus similarly to aqueous solutions potential-oxoacidity diagrams can be considered and the oxoacidity domain is imposed by the auto-dissociation reaction (1), related to the apparent constant $\mathrm{K}_{i}=\mathrm{a}\left(\mathrm{O}^{2-}\right) \cdot \mathrm{P}\left(\mathrm{H}_{2} \mathrm{O}\right)$, with $\mathrm{a}\left(\mathrm{O}^{2-}\right)$ the activity of oxide ions and $\mathrm{P}\left(\mathrm{H}_{2} \mathrm{O}\right)$ the partial pressure of water fixing the oxoacidity level. Thus, $\mathrm{pK}_{i}$ represents the accessible oxoacidity domain.

Electrochemically, the limiting reactions in reduction are the water reduction in acidic conditions or the alkali metal
(M) deposition in basic conditions; whereas for oxidation the reactions are hydroxide oxidation to superoxide in acidic conditions and oxide oxidation to peroxide in basic conditions (Eluard, 1970). It is important to note the presence and relative stability of these oxygenated species.

In oxoacidic conditions:

$$
\begin{aligned}
& 4 \mathrm{OH}^{-} \rightarrow \mathrm{O}_{2}^{-}+2 \mathrm{H}_{2} \mathrm{O}+3 \mathrm{e}^{-} \\
& 2 \mathrm{H}_{2} \mathrm{O}+2 \mathrm{e}^{-} \rightarrow \mathrm{H}_{2}+2 \mathrm{OH}^{-}
\end{aligned}
$$

In oxobasic conditions:

$$
\begin{gathered}
2 \mathrm{O}^{2-} \rightarrow \mathrm{O}_{2}^{2-}+2 \mathrm{e}^{-} \\
\mathrm{M}^{+}+\mathrm{e}^{-} \rightarrow \mathrm{M}
\end{gathered}
$$

Figure 1 shows a potential-oxoacidity diagram from the literature corresponding to varied oxygenated species in molten hydroxides (Goret, 1966). The existence of reduced oxygen species such as peroxide or superoxide ions at different oxoacidity levels evidence that the oxidative power of molten hydroxides can be modulated according to experimental conditions. The stability of metals, such as $\mathrm{Pt}, \mathrm{Ni}, \mathrm{Au}, \mathrm{Hg}, \mathrm{Cu}$, or $\mathrm{Mn}$, has also been investigated through this type of diagram (Goret, 1966; Eluard, 1970). This gives a general idea of the corrosion effects of molten hydroxides on metals. In most conditions, such metals are attacked through oxidation and oxoacidobasic reactions, either ionized and solubilized or as solid oxide, depending on their nature and solubility and on the potential imposed. In some cases, such as $\mathrm{Ni}$, the oxide layer $\left(\mathrm{NiO}\right.$ or $\left.\mathrm{NiO}_{2}\right)$ can lead to passivation as it is adherent and protects the underlying metal well, which explains why this element is considered among the best choices for use in molten hydroxides (Eluard, 1970). Other parameters such as nature of the salt and temperature are also of importance, e.g., in the case of sodium hydroxide, $\mathrm{Na}-\mathrm{Au}$ and $\mathrm{Na}$ Ag alloys can be obtained, and Ag could be considered for use at high-temperatures in oxidizing conditions because of the lack of stability of its oxides (Williams et al., 1956; Goret, 1966).

\section{APPLICATION OF HYDROXIDES IN ENERGY DEVICES}

\section{Molten Hydroxide Systems}

Firstly, molten hydroxides have been considered in a few studies for water splitting, either fundamentally by investigation of suitable electrodes (Sher et al., 2020), or directly by analyzing hydrogen production process (Licht et al., 2016). The main challenge faced is that for higher temperatures, the reaction kinetics are better and the splitting potential lower, but the hydrogen generation efficiency is also lower, as the hydroxides dehydrate, and then superoxide reduction competes with hydrogen formation. Thus the best water splitting electrolytes should be either lithium or barium hydroxide, as they retain hydration better. Indeed, a coulomb efficiency of $88 \%$ for hydrogen generation was reported in molten $\mathrm{LiOH}$ at $500^{\circ} \mathrm{C}$ (Licht et al., 2016). The use of molten $\mathrm{NaOH}-\mathrm{KOH}$ in ammonia fuel cell applications has also been investigated; a current density 
TABLE 1 | Data on some molten alkali hydroxides (Janz et al., 1968; Dauby et al., 1979; Claes and Gillbert, 1985).

\begin{tabular}{|c|c|c|c|}
\hline Species & Melting point $\left({ }^{\circ} \mathrm{C}\right)$ & Density at $427^{\circ} \mathrm{C}\left(\mathrm{g} \cdot \mathrm{cm}^{-3}\right)$ & Conductivity at $427^{\circ} \mathrm{C}\left(\Omega^{-1} \cdot \mathrm{cm}^{-1}\right)$ \\
\hline $\mathrm{NaOH}$ & 318 & 1.733 & 3.07 \\
\hline $\mathrm{KOH}$ & 360 & 1.705 & 2.68 \\
\hline $\mathrm{NaOH}-\mathrm{KOH}$ (51-49 mol\%) & 170 & $1.754\left(415^{\circ} \mathrm{C}\right)$ & $1.699\left(428^{\circ} \mathrm{C}\right)$ \\
\hline $\mathrm{LiOH}$ & 462 & $1.398\left(477^{\circ} \mathrm{C}\right)$ & $2.42\left(477^{\circ} \mathrm{C}\right)$ \\
\hline
\end{tabular}

of $16 \mathrm{~mW} \cdot \mathrm{cm}^{-2}$ at $220^{\circ} \mathrm{C}$ was obtained (Yang et al., 2014). However, molten hydroxides have mostly been used as an electrolyte in direct carbon fuel cells (DCFCs).

\section{Direct Carbon Fuel Cell}

Direct carbon fuel cell devices convert chemical energy into electrical energy by using solid carbon as a fuel, with a theoretical electrical yield close to $100 \%$, contrarily to classical hydrogen fuel cells (80-90\%) (Zecevic et al., 2004; Guo et al., 2013; Kacprzak, 2019; Kacprzak and Włodarczyk, 2020; Xing et al., 2021). They have very high efficiency, and can produce pure $\mathrm{CO}_{2}$, provided the carbon reactant is pure too. Indeed, the production of $\mathrm{CO}$ is not favored at the working temperatures (Kacprzak and Włodarczyk, 2020). The overall equation is:

$$
\mathrm{C}+\mathrm{O}_{2} \leftrightarrow \mathrm{CO}_{2}
$$

There are three major types of DCFCs depending on the electrolyte used: molten carbonates, solid oxide ceramics, or molten hydroxides. For the last case, usually a mixture of $\mathrm{NaOH}$, $\mathrm{KOH}$, and $\mathrm{LiOH}$ are used. The electrolyte is enclosed in a metallic container which is usually cast iron, and which serves as a cathode. The anode is carbon, which can be contained in a $\mathrm{Ni}$ mesh. A bubbler is added to produce small oxygen gas bubbles to improve oxygen transport to the cathode surfaces that can be seen in Figure 2.

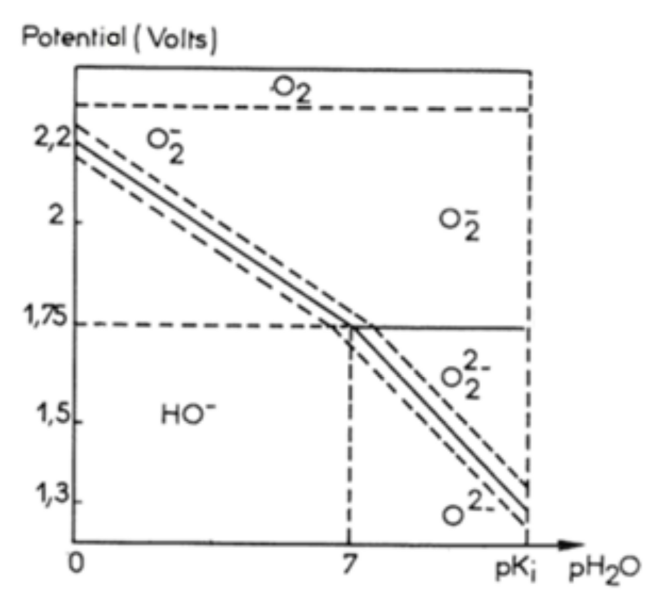

FIGURE 1 | Potential-oxoacidity diagram of oxygenated species in eutectic $\mathrm{NaOH}-\mathrm{KOH}$ at $227^{\circ} \mathrm{C}$ (Goret, 1966). Full line for $\mathrm{O}_{2}{ }^{-}$and $\mathrm{O}_{2}{ }^{2-}$ concentrations equal to $10^{-2} \mathrm{M}$, upper dashed line for $10^{-1} \mathrm{M}$ and lower dashed line for $10^{-3} \mathrm{M}$.

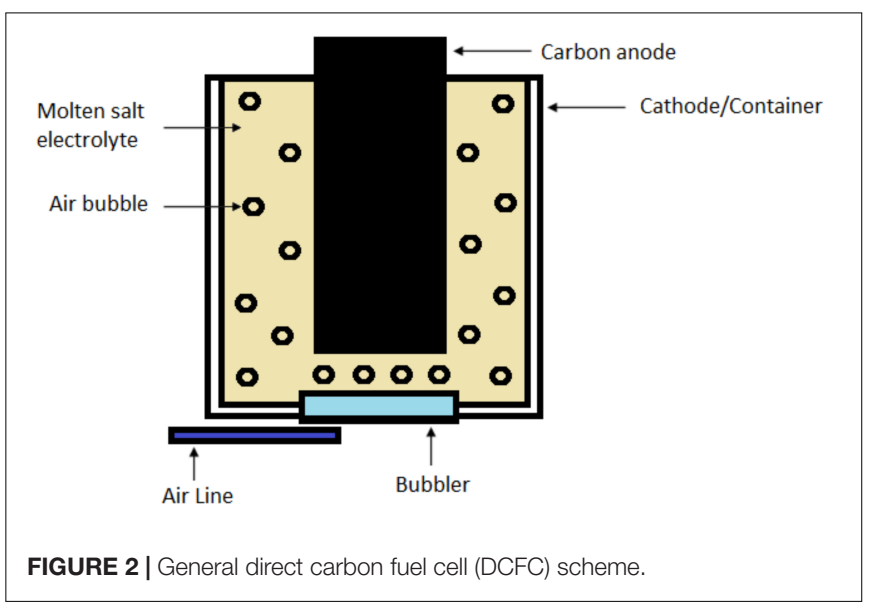

In molten hydroxide-based DCFCs, the electrochemical equations are:

$$
\begin{gathered}
\mathrm{C}+4 \mathrm{OH}^{-} \rightarrow 2 \mathrm{H}_{2} \mathrm{O}+\mathrm{CO}_{2}+4 \mathrm{e}^{-} \text {at the anode } \\
\mathrm{O}_{2}+2 \mathrm{H}_{2} \mathrm{O}+4 \mathrm{e}^{-} \rightarrow 4 \mathrm{OH}^{-} \text {at the cathode }
\end{gathered}
$$

Direct carbon fuel cells with molten hydroxide electrolyte have been reported in the literature (Zecevic et al., 2004; Guo et al., 2013; Kacprzak, 2019; Kacprzak and Włodarczyk, 2020; Xing et al., 2021). A current density of $100 \mathrm{~mA} \cdot \mathrm{cm}^{-2}$ between 400 and $500^{\circ} \mathrm{C}$ has been first reported in $\mathrm{NaOH}$ or $\mathrm{KOH}$ by Jacques in 1896. Guo et al. (2013) obtained up to $92 \mathrm{~mA} \cdot \mathrm{cm}^{-2}$ with $\mathrm{NaOH}$ at $550^{\circ} \mathrm{C}$ and up to $170 \mathrm{~mA} \cdot \mathrm{cm}^{-2}$ with $\mathrm{NaOH}-\mathrm{KOH}$ eutectic. Zecevic et al. (2004) managed to obtain a maximum current density above $250 \mathrm{~mA} \cdot \mathrm{cm}^{-2}$ and a maximum power of $180 \mathrm{~mW} \cdot \mathrm{cm}^{-2}$; however they worked at a higher temperature of $630^{\circ} \mathrm{C}$. The influence of parameters such as temperature, electrolyte, fuel type, and materials were also investigated in the literature (Kacprzak et al., 2013, 2014, 2016, 2017). It has been shown that the best corrosion resistance out of a number of tested materials in molten $\mathrm{NaOH}$, at temperatures from 673 to $923 \mathrm{~K}$, was displayed by $\mathrm{Ni}$ and its alloys such as Monel or Inconel, along with 301 stainless steel (Williams et al., 1956). However, the drawback of these DCFCs is that molten hydroxides can react, either chemically or electrochemically, as shown by Goret and Trémillon (1966, 1967):

$$
\begin{gathered}
\mathrm{CO}_{2}+2 \mathrm{OH}^{-} \rightarrow \mathrm{CO}_{3}^{2-}+\mathrm{H}_{2} \mathrm{O} \\
\mathrm{C}+6 \mathrm{OH}^{-} \rightarrow \mathrm{CO}_{3}^{2-}+3 \mathrm{H}_{2} \mathrm{O}+4 \mathrm{e}^{-}
\end{gathered}
$$

These issues can be resolved by providing water to the DCFC, which will prevent the dissociation of hydroxides and, thus, 


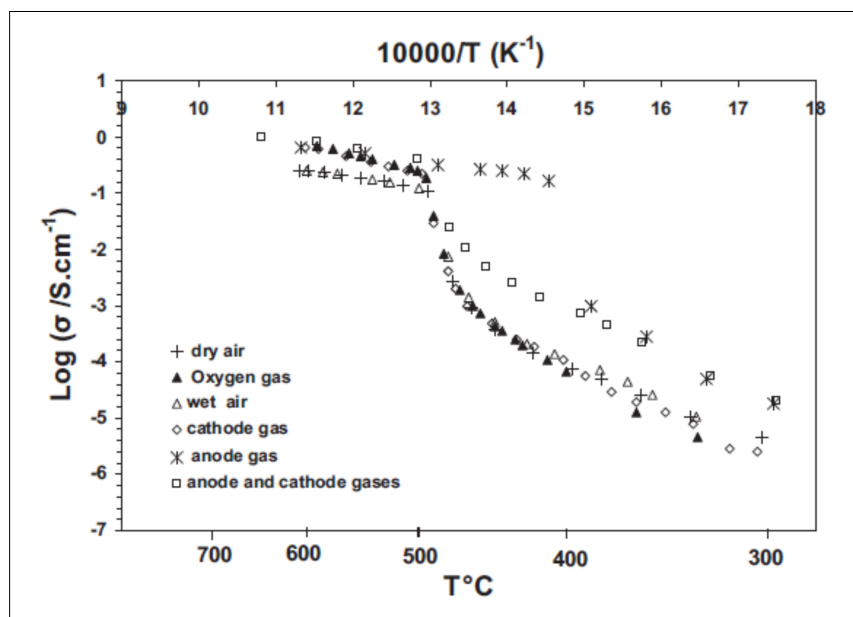

FIGURE 3 | Arrhenius plots of the conductivity of a GDC/ 30\% Li-K sample under different atmospheres (Benamira et al., 2012).

the reactions given above. Besides, water has a few other advantages, such as increasing ionic conductivity, reducing corrosion by decreasing the concentration of oxygen species (oxides, peroxides, and superoxides) in the melt (Zecevic et al., 2004; Kacprzak, 2019). However, it has been found that this water effect requires temperatures of $650^{\circ} \mathrm{C}$ or more (Zecevic et al., 2004). Besides, a low carbon dioxide pressure is preferable to further inhibit the reactivity (Hemmes and Cassir, 2011). Finally, there still are some remaining problems that should be addressed such as the best carbon structure for optimal reactivity, the possible effects of fuel impurities, corrosion issues due to molten hydroxides, and scale-up of the technology (Kacprzak and Włodarczyk, 2020).

\section{Hybrid Fuel Cell}

Hybrid fuel cells are a type of fuel cell combining molten carbonate and solid oxide technologies, through a composite electrolyte usually composed by a zirconia or ceria-based phase and a molten carbonate phase. Xiong et al. (2015) have shown in the case of a $\mathrm{BaZr}_{0 \cdot 8} \mathrm{Y}_{0 \cdot 2} \mathrm{O}_{3-\delta} / \mathrm{Li}-\mathrm{Na}$ composite electrolyte that the conductivity in the carbonate phase is enhanced under $\mathrm{H}_{2}$ or $\mathrm{H}_{2} \mathrm{O}$ compared to air and that it increased with $\mathrm{H}_{2} \mathrm{O}$ pressure. Thus the appearance of a new proton conducting species in the carbonate phase was suggested, the species could be $\mathrm{OH}^{-}$and $\mathrm{HCO}_{3}{ }^{-}$. Benamira et al. (2012) have found similar results for GDC (Gadolinia Doped Ceria)/Li-K and GDC/Li-Na composites, with very high conductivities being obtained under anode gas conditions (so under $\mathrm{H}_{2}$ and $\mathrm{CO}_{2}$ ), as evidenced in Figure 3 .

It can be seen that the transition occurs at around $415^{\circ} \mathrm{C}$ for this electrolyte under anode gas conditions even though the $\mathrm{Li}-\mathrm{K}$ carbonate eutectic melts at around $485^{\circ} \mathrm{C}$, so this could evidence the formation of hydroxides that melt at lower temperature. Both the melting point and the higher conductivity are arguments for hydroxide formation. The trends are more pronounced for $\mathrm{Li}-\mathrm{K}$ than $\mathrm{Li}-\mathrm{Na}$, but present in both cases nonetheless.
This behavior has once again been highlighted by Grishin (2019) in his Ph.D. work for an SDC (Samaria Doped Ceria)/LiNa-K electrolyte. The hydroxide formation was evidenced not just by conductivity, but also by TGA/DSC and XRD analyses, under hydrogen and even more under wet hydrogen. Samples analyzed with 2 TGA/DSC cycles reveal the formation of hydroxides through the lower overall fusion temperature obtained for the second cycle, and through lower temperature endothermic peaks in the second cycle at around $315^{\circ} \mathrm{C}$, which were attributed to $\mathrm{NaOH}$ fusion. A new hydrated phase was also observed by XRD analyses of samples that were cycled under dry and wet hydrogen: $\mathrm{NaK}_{2}\left[\mathrm{H}\left(\mathrm{CO}_{3}\right)_{2}\right] \cdot 2 \mathrm{H}_{2} \mathrm{O}$, which could support hydroxide presence as they can create other phases with carbonates.

\section{Hydroxide Interference in MCFC}

Hydroxides are also present in standard MCFCs. Indeed, as water is an inlet gas, there is, similarly to carbonate/carbon dioxide, the previously introduced oxoacid/oxobase equilibrium (1). Then hydroxides can also react in an oxoacidobasic reaction with $\mathrm{CO}_{2}$, through reaction (9). This shows that a sufficient water pressure allows for hydroxides to exist and be stable in MCFC conditions. Although the presence of molten hydroxides is likely in molten carbonates due to the presence of water, it is only until recently that their significant role has been demonstrated in the literature. Indeed, new studies show that these ions also contribute to overall MCFC performance in some conditions (Audasso et al., 2020; Rosen et al., 2020). For $\mathrm{CO}_{2}$-lean wet atmospheres, very high current densities, and/or high $\mathrm{CO}_{2}$ usage, the MCFC can also operate using hydroxide as charge carrier, along with carbonates. Rosen et al. (2020) have noticed that compared to their simulations, the effective $\mathrm{CO}_{2}$ utilization rate in carbon capture conditions was lower. In Figure 4, they plotted real MCFC utilization rate vs. simulated, and observed that their real $\mathrm{CO}_{2}$ utilization was lowest for low anode inlet $\mathrm{CO}_{2}(2 \%)$ when comparing different atmospheres. The difference was also larger for high current densities at a given $\mathrm{CO}_{2}$ percentage, and for high water content. However, it was negligible for a higher inlet $\mathrm{CO}_{2}$ of $17 \%$. By observing OCP variation, they found at low inlet $\mathrm{CO}_{2}$ that the dependence on $\mathrm{CO}_{2}$ is not the same, indicating a different phenomenon is occurring as the OCP deviates from expected Nernst potential. Mass balance experiments on water proved that for dilute $\mathrm{CO}_{2}$ conditions, water amount collected is somehow lower at the cathode and higher at the anode. All these results indicate that water is responsible for another charge carrier in these dilute $\mathrm{CO}_{2}$ concentrations. This charge carrier is the hydroxide anion, which has been shown to be the main hydrated ion in the considered conditions, namely a temperature of $650^{\circ} \mathrm{C}$ (Frangini et al., 2014), as will be detailed in the following part about water reduction and hydrogen oxidation reactions in molten carbonates. In addition, Evans et al. (2015) also observed hydroxide transport in molten carbonates in wet conditions.

Figure 5 recapitulates the reactions taking place at both anode and cathode side for both possible charge carriers.

Audasso et al. (2020) then proposed a dual-anion model to more accurately describe MCFC performance. In 

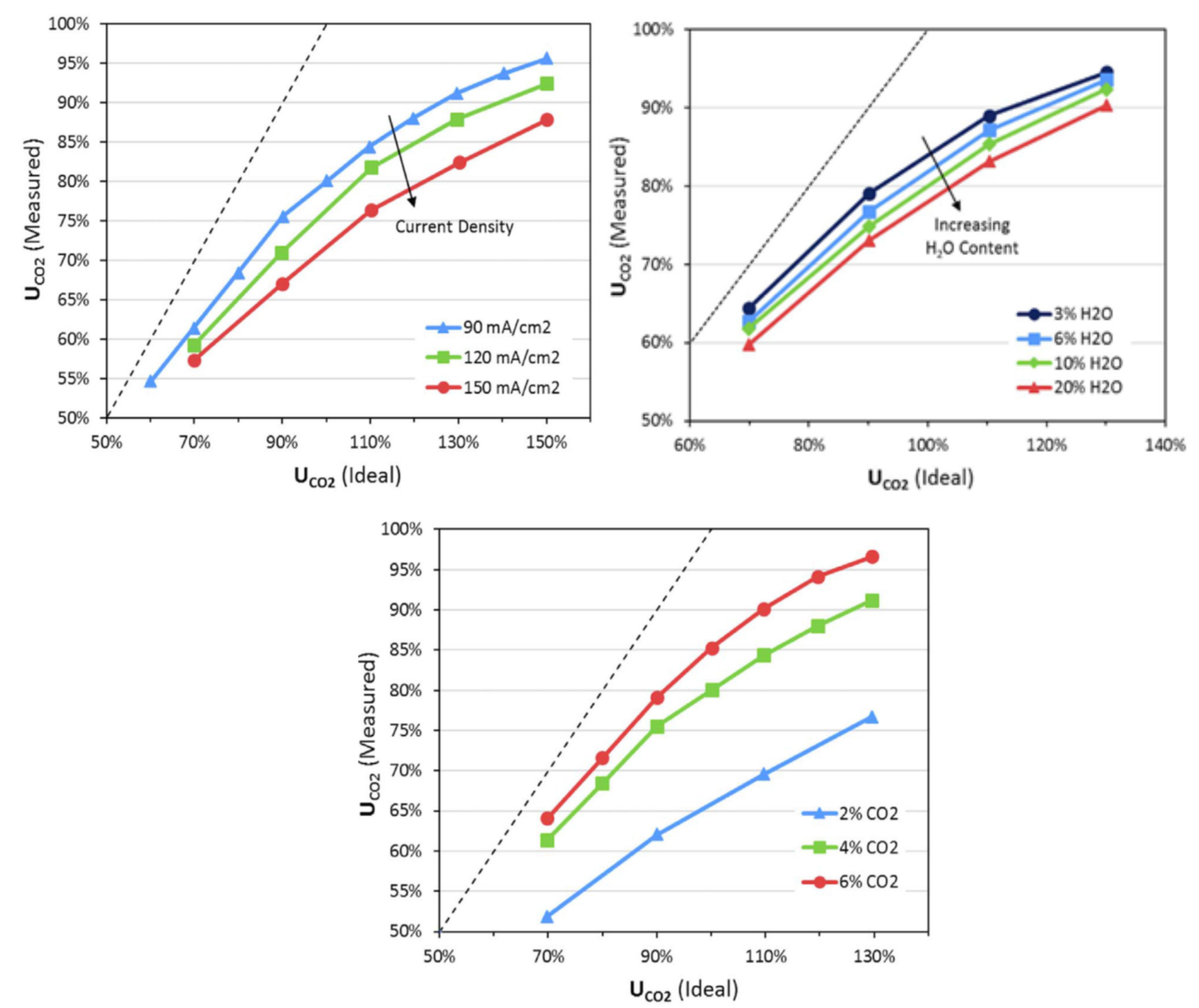

FIGURE 4 | Plots of measured $\mathrm{CO}_{2}$ utilization rate versus expected, for various current densities, water contents, and $\mathrm{CO}_{2}$ contents (Rosen et al., 2020).

such case, the net current is distributed in two different circuits, for the carbonate and hydroxide paths, as shown in Figure 6.

\section{Role in $\mathrm{H}_{2}$ Oxidation and $\mathrm{H}_{2} \mathrm{O}$ Reduction Mechanism}

Some widely accepted $\mathrm{H}_{2}$ oxidation mechanisms in molten carbonates include intermediate hydroxide species. Three main mechanisms have been suggested by Ang and Sammels, Jewulski and Suski, and White and Twardoch. The first one, using hydroxides, and suggested by Ang and Sammells (1980), is:

$$
\begin{gathered}
\mathrm{H}_{2}+2 \mathrm{M} \leftrightarrow 2 \mathrm{M}-\mathrm{H} \\
\mathrm{M}-\mathrm{H}+\mathrm{CO}_{3}^{2-} \leftrightarrow \mathrm{OH}^{-}+\mathrm{CO}_{2}+\mathrm{M}+\mathrm{e}^{-} \\
\mathrm{M}-\mathrm{H}+\mathrm{OH}^{-} \leftrightarrow \mathrm{H}_{2} \mathrm{O}+\mathrm{M}+\mathrm{e}^{-}
\end{gathered}
$$

Another hydroxide mechanism suggested by Jewulski and Suski (1984) is:

$$
\begin{gathered}
\mathrm{H}_{2}+2 \mathrm{M} \leftrightarrow 2 \mathrm{M}-\mathrm{H} \\
2\left\{\mathrm{M}-\mathrm{H}+\mathrm{CO}_{3}^{2-} \leftrightarrow \mathrm{OH}^{-}+\mathrm{CO}_{2}+\mathrm{M}+\mathrm{e}^{-}\right\} \\
2 \mathrm{OH}^{-}+\mathrm{CO}_{2} \leftrightarrow \mathrm{H}_{2} \mathrm{O}+\mathrm{CO}_{3}^{2-}
\end{gathered}
$$

Finally, White and Twardoch (1984, 1987) suggested bicarbonates instead of carbonates as an intermediate species, in the following mechanism:

$$
\begin{gathered}
\mathrm{H}_{2}+2 \mathrm{M} \leftrightarrow 2 \mathrm{M}-\mathrm{H} \\
2\left\{\mathrm{M}-\mathrm{H}+\mathrm{CO}_{3}^{2-} \leftrightarrow \mathrm{HCO}_{3}^{-}+\mathrm{M}+\mathrm{e}^{-}\right\} \\
2 \mathrm{HCO}_{3}^{-} \leftrightarrow \mathrm{H}_{2} \mathrm{O}+\mathrm{CO}_{3}^{2-}+\mathrm{CO}_{2}
\end{gathered}
$$



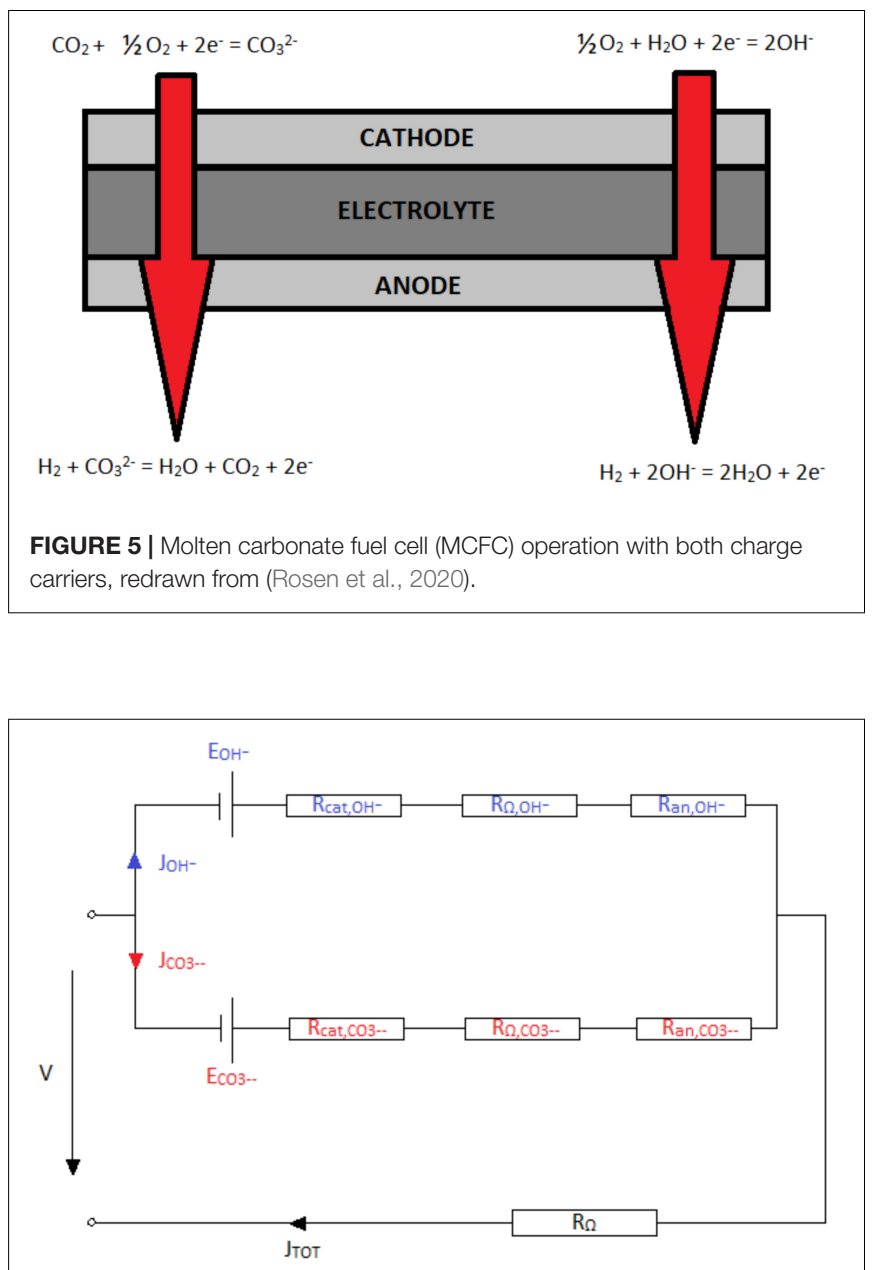

FIGURE 6 | Equivalent circuit describing MCFC operation, redrawn from Audasso et al. (2020).

Applying the principle of microscopic reversibility, the water reduction mechanism in molten carbonates would be the exact opposite of the hydrogen oxidation one (Frangini et al., 2014).

Nishina et al. (1990) studied the $\mathrm{H}_{2}$ oxidation in the $\mathrm{Li}-\mathrm{K}$ eutectic at $650^{\circ} \mathrm{C}$, at various metal electrodes, using cyclic voltammetry, electrochemical impedance spectroscopy and chronocoulometry. They compared their findings to the three pathways proposed in the literature, only to conclude that the $\mathrm{H}_{2}$ oxidation mechanism in their case was better described by mechanism 2, suggested by Jewulski and Suski.

Later, Frangini et al. (2014) studied the water reduction mechanism for temperatures ranging from $500^{\circ} \mathrm{C}$ to $600^{\circ} \mathrm{C}$, in the Li-Na-K ternary eutectic over gold. They found by cyclic voltammetry that for temperatures below $550^{\circ} \mathrm{C}$, the reaction was bicarbonate-assisted, whereas for temperatures above $550^{\circ} \mathrm{C}$ the mechanism involved hydroxides. This was consistent with predicted equilibrium concentrations involving both intermediate species in $\mathrm{Li}-\mathrm{Na}-\mathrm{K}$, as bicarbonate concentration indeed becomes negligible above $550^{\circ} \mathrm{C}$ (Frangini et al., 2014).

\section{Role in Cathode Mechanism}

In the MCFC, the cathodic oxygen reduction reaction is:

$$
\frac{1}{2} \mathrm{O}_{2}+\mathrm{CO}_{2}+2 \mathrm{e}^{-} \rightarrow \mathrm{CO}_{3}^{2-}
$$

The mechanism of this reaction has been extensively investigated in the literature (Appleby and Nicholson, 1974, 1977, 1980; Lu and Selman, 1990, 1992; Moutiers et al., 1991, 1992; Nishina et al., 1994, 1996; Cassir et al., 1997), with 3 main paths being proposed, the Superoxide Path (SOP), the Peroxide Path (POP), and possibly the Peroximonocarbonate Path (POCP).

SOP:

$$
\begin{aligned}
3 \mathrm{O}_{2}+2 \mathrm{CO}_{3}^{2-} \leftrightarrow 4 \mathrm{O}_{2}^{-}+2 \mathrm{CO}_{2} \\
\mathrm{O}_{2}^{-}+\mathrm{e}^{-} \rightarrow \mathrm{O}_{2}^{2-} \\
\mathrm{O}_{2}^{2-}+2 \mathrm{e}^{-} \rightarrow 2 \mathrm{O}^{2-} \\
\mathrm{O}^{2-}+\mathrm{CO}_{2} \leftrightarrow \mathrm{CO}_{3}^{2-}
\end{aligned}
$$

POP:

$$
\begin{gathered}
\mathrm{O}_{2}+2 \mathrm{CO}_{3}^{2-} \leftrightarrow 2 \mathrm{O}_{2}^{2-}+2 \mathrm{CO}_{2} \\
\mathrm{O}_{2}^{2-}+2 \mathrm{e}^{-} \rightarrow 2 \mathrm{O}^{2-} \\
\mathrm{O}^{2-}+\mathrm{CO}_{2} \leftrightarrow \mathrm{CO}_{3}^{2-}
\end{gathered}
$$

POCP (hypothetical):

$$
\begin{gathered}
\mathrm{O}_{2}+2 \mathrm{CO}_{3}^{2-} \leftrightarrow 2 \mathrm{CO}_{4}^{2-} \\
\mathrm{CO}_{4}^{2-}+2 \mathrm{e}^{-} \rightarrow \mathrm{O}^{2-}+\mathrm{CO}_{3}^{2-} \\
\mathrm{O}^{2-}+\mathrm{CO}_{2} \leftrightarrow \mathrm{CO}_{3}^{2-}
\end{gathered}
$$

As molecular oxygen is not stable in these molten salts, these mechanisms involve reduced oxygenated species such as superoxides or peroxides. In most cases, $\mathrm{CO}_{2}$ diffusion dominates the reaction process (Arato et al., 2016).

Some research groups observed, either experimentally (Nishina et al., 1996; Audasso et al., 2017) or by modeling (Arato et al., 2016), a water effect on the cathode reaction: presence of water vapor decreased the apparent diffusion resistance of $\mathrm{CO}_{2}$ and increased apparent mass transfer. This behavior was to be expected, as it has previously been explained that water reacts as an oxide ion acceptor, linked to its conjugated oxobase $\mathrm{OH}^{-}$by reaction 1 , and can be later reobtained through reaction 9 reversed. There is then coexistence of reactions 1 and 21 to neutralize the oxide ion.

In a real MCFC, the presence of $\mathrm{H}_{2} \mathrm{O}$ at the cathode side is beneficial for fuel cell performance, through higher voltage, and lower overall impedance (Audasso et al., 2017). This is especially true for low inlet $\mathrm{CO}_{2}$.

\section{Co-electrolysis}

Recently, some research groups have proposed the direct coelectrolysis of $\mathrm{CO}_{2}$ and $\mathrm{H}_{2} \mathrm{O}$ through reduction of carbonates and hydroxides. In this case, alkali metal hydroxides such as $\mathrm{LiOH}, \mathrm{NaOH}$, and $\mathrm{KOH}$ have been used as additives in molten 


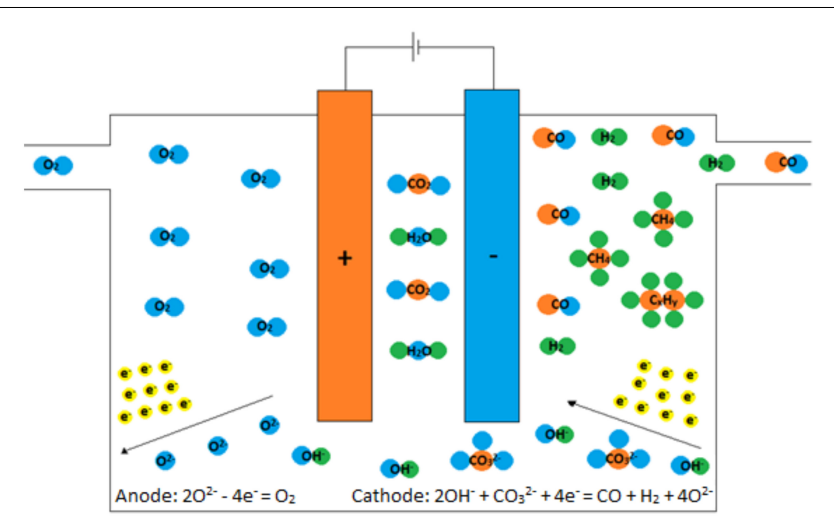

FIGURE 7 | Scheme of the electrolysis system, redrawn from Liu et al. (2017).

carbonates as a monovalent hydrogen source in $\mathrm{CO}_{2}$ capture and conversion to generate syngas, methane or other hydrocarbons (Wu et al., 2016; Liu et al., 2017; Li et al., 2018; Ji et al., 2019). Addition of certain amount of alkali hydroxides may also decrease the melting point of the resulting molten salt mixture with respect to pristine carbonate eutectic, which is an important parameter as lower operating temperatures can be used. In a mixed alkali carbonate/hydroxide melt, the electrochemical reactions for co-electrolysis are proposed as follows:

$$
\begin{aligned}
4 \mathrm{OH}^{-}+\mathrm{CO}_{3}^{2-}+8 \mathrm{e}^{-} \rightarrow & \mathrm{CH}_{4}+7 \mathrm{O}^{2-} \\
& \text { for methane production (31) } \\
2 \mathrm{OH}^{-}+\mathrm{CO}_{3}^{2-}+4 \mathrm{e}^{-} \rightarrow & \mathrm{CO}+\mathrm{H}_{2}+4 \mathrm{O}^{2-} \\
& \text { for } \mathrm{CO} \text { production }
\end{aligned}
$$

The electrolyte could be renewed by the reaction of oxide ions with $\mathrm{CO}_{2}$ and water:

$$
\begin{gathered}
\mathrm{O}^{2-}+\mathrm{H}_{2} \mathrm{O} \rightarrow 2 \mathrm{OH}^{-} \\
\mathrm{O}^{2-}+\mathrm{CO}_{2} \rightarrow \mathrm{CO}_{3}^{2-}
\end{gathered}
$$

The oxide ion can also be oxidized:

$$
2 \mathrm{O}^{2-} \rightarrow \mathrm{O}_{2}+4 \mathrm{e}^{-}
$$

Thus the full reactions are, including regeneration, the simple electrolysis equations of $\mathrm{CO}_{2}$ and $\mathrm{H}_{2} \mathrm{O}$ to $\mathrm{CH}_{4}$ or syngas:

$$
\begin{aligned}
& \mathrm{CO}_{2}+2 \mathrm{H}_{2} \mathrm{O} \rightarrow \mathrm{CH}_{4}+2 \mathrm{O}_{2} \\
& \mathrm{CO}_{2}+\mathrm{H}_{2} \mathrm{O} \rightarrow \mathrm{CO}+\mathrm{H}_{2}+\mathrm{O}_{2}
\end{aligned}
$$

Such reactions have been reported in a two-electrode setup, using $\mathrm{Ni}$ anode and Fe cathode. A scheme is given in Figure 7.

The effect of different parameters such as temperature, nature of the electrolyte (including alkali hydroxide) and electrolysis potential have been investigated focussing on the efficiency and nature of the gaseous product. It is worth mentioning that without added water, solid carbon is the preferred thermodynamic product of carbon dioxide splitting, having a lower electrolysis potential at temperatures below $800^{\circ} \mathrm{C}$, and carbon monoxide being favoured at higher temperatures. Experimentally, carbon deposition was observed at the cathode even at temperatures above $800^{\circ} \mathrm{C}$ (Wu et al., 2016). However, with the addition of hydroxides in molten carbonates, carbon deposition was only observed in lean mixtures of hydroxides (with a molar ratio of hydroxides to carbonates in the eutectic electrolyte $<0.05)$. Among $\mathrm{Li}, \mathrm{Na}$, and $\mathrm{K}$ hydroxides, lithium hydroxide seems to be a better choice of additive. Indeed, both $\mathrm{KOH}$ and $\mathrm{NaOH}$ present a lower cation to metal reduction potential, which is a serious issue as they can be parasitic side reactions (Liu et al., 2017). Li deposition is relatively low compared to the other alkali metals. $\mathrm{LiOH}$ also remains hydrated more easily than $\mathrm{NaOH}$ or $\mathrm{KOH}$, as it has been reported to sustain $\mathrm{LiOH}-9 \mathrm{H}_{2} \mathrm{O}$ above $350^{\circ} \mathrm{C}$ (Wu et al., 2016). It also has a greater charge density because it has the same univalent charge as the others but dispersed over a smaller volume, so the choice of $\mathrm{LiOH}$ might improve the conductivity. Finally, usual anode material, nickel, is also more stable in electrolytes containing high content of $\mathrm{Li}^{+}$compared to $\mathrm{Na}^{+}$or $\mathrm{K}^{+}$. In terms of temperature, the studies have been focused in the $500^{\circ} \mathrm{C}-600^{\circ} \mathrm{C}$ range. A general

\begin{tabular}{|c|c|c|c|c|}
\hline Electrolyte & Temperature $\left({ }^{\circ} \mathrm{C}\right)$ & Potential or current & Efficiency (\%) & Product \\
\hline \multirow[t]{3}{*}{$\mathrm{Li}_{1.07}-\mathrm{Na}_{0.93} \mathrm{CO}_{3}-0.1 \mathrm{LiOH}$} & 550 & $1.8 \mathrm{~V}$ & $\sim 45$ & $55 \%$ CO \\
\hline & & & & $35 \% \mathrm{H}_{2}$ \\
\hline & & & & $10 \% \mathrm{C}_{x} \mathrm{H}_{y}$ \\
\hline \multirow[t]{2}{*}{$\mathrm{Li}_{1.51} \mathrm{~K}_{0.49} \mathrm{CO}_{3}-0.1 \mathrm{LiOH}$} & 550 & $1.6 \mathrm{~V}$ & $\sim 45$ & $\sim 60 \% \mathrm{CO}$ \\
\hline & & & & $\sim 40 \% \mathrm{H}_{2}$ \\
\hline \multirow[t]{3}{*}{$\mathrm{Li}_{1.43} \mathrm{Na}_{0.36} \mathrm{~K}_{0.21} \mathrm{CO}_{3}-0.1 \mathrm{LiOH}$} & 550 & $1.8 \mathrm{~V}$ & $\sim 65$ & $62 \% \mathrm{CO}$ \\
\hline & & & & $33 \% \mathrm{H}_{2}$ \\
\hline & & & & $5 \% \mathrm{C}_{x} \mathrm{H}_{y}$ \\
\hline \multirow[t]{2}{*}{$\mathrm{Li}_{0.85} \mathrm{Na}_{0.61} \mathrm{~K}_{0.54}-0.15 \mathrm{Ca}(\mathrm{OH})_{2}$} & 575 & $15 \mathrm{~mA} \mathrm{~cm}^{-2}$ & 92.88 & $63.34 \% \mathrm{CH}_{4}$ \\
\hline & & & & $35.81 \% \mathrm{H}_{2}$ \\
\hline
\end{tabular}
trend is that $\mathrm{CO}$ production is optimal at $550^{\circ} \mathrm{C}$ and that higher temperatures tended to favor $\mathrm{H}_{2}$ or methane more. Regarding the potential, explored between 1.6 and $2.6 \mathrm{~V}$, CO generation is favored at $1.8 \mathrm{~V}$, as higher potentials resulted in more hydrogen. Finally, in terms of electrolyte, the ones containing a high fraction of $\mathrm{Li}_{2} \mathrm{CO}_{3}$ favoured $\mathrm{CO}$ generation. Regarding syngas production, $\mathrm{Li}_{0.85} \mathrm{Na}_{0.61} \mathrm{~K}_{0.54}-0.1 \mathrm{LiOH}$ was the best tested

TABLE 2 | Some syngas and methane generation results (Wu et al., 2016; Liu et al., 2017; Li et al., 2018; Ji et al., 2019). 
mixture, with an efficiency close to $93 \%$. However, it produced a relatively low fraction of CO (25\%). CO was generated in higher proportions in electrolytes where the carbonates are just a binary mixture, but with efficiencies lower than $60 \%$. At temperatures of $550^{\circ} \mathrm{C}$ and higher, by applying current densities between 2.5 and $30 \mathrm{~mA} \mathrm{~cm}^{-2}$, methane is generated. For this gas specifically, the best hydroxide ratio is 0.15 and the best electrolyte featuring a ternary carbonates mixture. Higher hydroxide content mean more hydrogen and less methane, but a ratio of at least 0.15 enables efficiencies higher than $90 \%$. A gas outlet of $63.34 \% \mathrm{CH}_{4}$ and $35.81 \% \mathrm{H}_{2}$ was obtained in $\mathrm{Li}_{0.85} \mathrm{Na}_{0.61} \mathrm{~K}_{0.54}-0.15 \mathrm{Ca}(\mathrm{OH})_{2}$ at $575^{\circ} \mathrm{C}$ under $15 \mathrm{~mA} \cdot \mathrm{cm}^{-2}$ with $92.88 \%$ Faraday efficiency. Overall, the main results are summarized in Table 2.

\section{CONCLUSION}

Hydroxides are a key component in high-temperature fuel cell systems, and specifically MCFC/MCECs, due to their contributions as intermediates for water reduction in electrolysis mode, as charge carrier species and as direct hydrogen source in electrolysis. These ions have to be accounted for in order to gain full understanding of most high-temperature fuel cell systems operating under hydrogen or water. Besides, their properties, especially their low melting point and high conductivity, are also a great asset in order to enhance performances of fuel

\section{REFERENCES}

Ang, P. G. P., and Sammells, A. F. (1980). Influence of electrolyte composition on electrode kinetics in the molten carbonate fuel cell. J. Electrochem. Soc. 127, 1287-1294. doi: 10.1149/1.2129873

Appleby, A. J., and Nicholson, S. B. (1974). The reduction of oxygen in molten lithium carbonate. J. Electroanal. Chem. 53, 105-119. doi: 10.1016/00220728(74)80007-0

Appleby, A. J., and Nicholson, S. B. (1977). Reduction of oxygen in alkali carbonate melts. J. Electroanal. Chem. 83, 309-328. doi: 10.1016/S0022-0728(77)80176-9

Appleby, A. J., and Nicholson, S. B. (1980). Reduction of oxygen in lithiumpotassium carbonate melt. J. Electroanal. Chem. 112, 71-76. doi: 10.1016/ S0022-0728(80)80008-8

Arato, E., Audasso, E., Barelli, L., Bosio, B., and Discepoli, G. (2016). Kinetic modelling of molten carbonate fuel cells: Effects of cathode water and electrode materials. J. Power Sour. 330, 18-27. doi: 10.1016/j.jpowsour.2016.08.123

Audasso, E., Barelli, L., Bidini, G., Bosio, B., and Discepoli, G. (2017). Molten carbonate fuel cell performance analysis varying cathode operating conditions for carbon capture applications. J. Power Sour. 348, 118-129. doi: 10.1016/j. jpowsour.2017.02.081

Audasso, E., Bosio, B., Bove, D., Arato, E., Barckholtz, T., Kiss, G., et al. (2020). New, dual-anion mechanism for molten carbonate fuel cells working as carbon capture devices. J. Electrochem. Soc. 167:084504. doi: 10.1149/1945-7111/ ab8979

Benamira, M., Ringuedé, A., Hildebrandt, L., Lagergren, C., Vannier, R.-N., and Cassir, M. (2012). Gadolinia-doped ceria mixed with alkali carbonates for SOFC applications: II - An electrochemical insight. Int. J. Hydrogen Energ. 37, 19371-19379. doi: 10.1016/j.ijhydene.2011.10.062

Cassir, M., Malinowska, M., Peelen, W., Hemmes, K., and De Wit, J. H. W. (1997). Identification and electrochemical characterization of in situ produced reduced oxygen species in molten $\mathrm{Li}-\mathrm{K}$ carbonate under $\mathrm{P}(\mathrm{CO} 2)=1$ atm and $\mathrm{P}(\mathrm{CO} 2)$ $=0.1 \mathrm{~atm}+\mathrm{P}(\mathrm{O} 2)=0.9 \mathrm{~atm}$. Influence of oxide, peroxide and superoxide additions. J. Electroanal. Chem. 433, 195-205. doi: 10.1016/S0022-0728(97) 00292-1 cells and carry out efficient co-electrolysis of $\mathrm{CO}_{2}$ and $\mathrm{H}_{2} \mathrm{O}$. It is amazing how such interesting molten salts with outstanding properties have been investigated in the past in dispersed applications, then forgotten, are experiencing renewed interest not only for their direct applications as electrolytes (DCFCs, catalysis, reactive media, electrosynthesis, etc.), but also for their significant participation in electrode processes where the electrolyte is mainly composed of molten carbonates or hybrid molten carbonates/solid oxides. This opens an important area of research, knowing that the corrosion effect of molten hydroxides should be well understood and controlled.

\section{AUTHOR CONTRIBUTIONS}

MC wrote part of the review. EGü contributed in the whole manuscript elaboration. EGr wrote specific parts on the MCFC technology. AR contributed mainly in the part on the hybrid fuel cells. VL contributed in the electrolysis part. All authors contributed to the article and approved the submitted version.

\section{FUNDING}

This work was supported by the French program ANR MCEC 17-CE05-0025-01.

Cassir, M., McPhail, S. J., and Moreno, A. (2012). Strategies and new developments in the field of molten carbonates and high temperature fuel cells in the carbon cycle. Int. J. Hydrogen Energ. 37, 19345-19350. doi: 10.1016/j.ijhydene.2011. 11.006

Claes, P., and Gilbert, J. (1985). Electrical conductivity and specific mass of the molten $\mathrm{LiOH}-\mathrm{LiNO} 3, \mathrm{NaOH}-\mathrm{NaNO} 3$, and $\mathrm{KOH}-\mathrm{KNO} 3$ mixtures. J. Electrochem. Soc. 132, 857-862. doi: 10.1002/chin.198529014

Claes, P., Mernier, F., Wery, L., and Glibert, J. (1999). Composition dependence of the oxoacidobasic properties of molten hydroxides. Electrochim. Acta 44, 3999-4006. doi: 10.1016/S0013-4686(99)00122-X

Dauby, C., Glibert, J., and Claes, P. (1979). Electrical conductivity and specific mass of the molten $\mathrm{NaOH}-\mathrm{KOH}$ eutectic mixture. Electrochim. Acta 24, 35-39. doi: 10.1016/0013-4686(79)80037-7

Eluard, A. (1970). Contribution à l'étude des Propriétés Chimiques et Électrochimiques en Solution Dans les Hydroxydes Alcalins Fondus. Ph. D. Dissertation, University of Paris, Paris.

Evans, A., Xing, W., and Norby, T. (2015). Electromotive force (emf) determination of transport numbers for native and foreign ions in molten alkali metal carbonates. J. Electrochem. Soc. 162, F1135-F1143. doi: 10.1149/ 2.0121510jes

Frangini, S., Felici, C., and Tarquini, P. (2014). A novel process for solar hydrogen production based on water electrolysis in alkali molten carbonates. ECS Trans. 61, 13-25. doi: 10.1149/06122.0013ecst

Fuel Cell Energy (2017). Carbon Capture with Direct Fuel Cell Carbonate Powerplants. Available online at: http://www.sccs.org.uk/images/events/2017/ 8-Carbon-Capture-with-DFC-Fuel-Cells-022117a.pdf (accessed June 27, 2019)

Fuel Cell Energy (2019). Fuel Cell Energy Announces New Carbon Capture Project with Drax Power Station. Available online at: http://www.globenewswire.com (accessed June 27, 2019)

Goret, J. (1966). Réactions Chimiques et Électrochimiques Dans les Hydroxydes Alcalins Fondus. Ph. D. Dissertation, University of Paris, Paris.

Goret, J., and Trémillon, B. (1966). Propriétés Chimiques et Électrochimiques en Solution Dans les Hydroxydes Alcalins Fondus-III. Complexes Oxyde et Acidité 
de Quelques Cations Métalliques. Extrait du Bulletin de la Société Chimique de France. Paris: Société Chimique de France, 2872.

Goret, J., and Trémillon, B. (1967). Propriétés chimiques et électrochimiques en solution dans les hydroxydes alcalins fondus-IV. Comportement électrochimique de quelques métaux utilisés comme électrodes indicatrices. Electrochim. Acta 12, 1065-1083. doi: 10.1016/0013-4686(67)80103-8

Grishin, A. (2019). Réactivité Interfaciale des Composés à Base de CeO2 Dans des Dispositifs Électrochimiques Hybrides Fonctionnant à Haute Température. Ph. D. Dissertation, PSL Research University, Paris.

Gunnarson, G. (2009). "Lifetime of sodium beta-alumina membranes in molten sodium hydroxide," in Report of Project Supported by the USAF European Office of Aerospace Research and Development ( $N^{\circ}$ FA8655-07-3064). Reykjavík: Innovation Center Iceland, 1-13.

Guo, L., Calo, J. M., DiCocco, E., and Bain, E. J. (2013). Development of a low temperature, molten hydroxide direct carbon fuel cell. Energ. Fuel 27, 1712-1719. doi: 10.1021/ef302100h

Hemmes, K., and Cassir, M. (2011). A theoretical study of the Carbon/Carbonate/Hydroxide (Electro-) chemical system in a direct carbon fuel cell. J. Fuel Cell Sci. Tech. 8:051005. doi: 10.1115/1.4003750

Hu, L., Rexed, I., Lindbergh, G., and Lagergren, C. (2014). Electrochemical performance of reversible molten carbonate fuel cells. Int. J. Hydrogen Energ. 39, 12323-12329. doi: 10.1016/j.ijhydene.2014.02.144

Intergovernmental Panel on Climate Change (2005). IPCC Special Report on Carbon Dioxide Capture and Storage, ed. B. Metz Cambridge: Cambridge University Press.

Janz, G. J., Dampier, F. W., Lakshminarayanan, G. R., Lorenz, P. K., and Tomkins, R. P. T. (1968). Molten Salts: Volume 1, Electrical Conductance, Density, and Viscosity Data. Gaithersburg, MD: US National Bureau of Standards.

Jewulski, J., and Suski, L. (1984). Model of the isotropic anode in the molten carbonate fuel cell. J. Appl. Electrochem. 14, 135-143. doi: 10.1007/BF00618732

Ji, D., Li, Z., Li, W., Yuan, D., Wang, Y., Yu, Y., et al. (2019). The optimization of electrolyte composition for $\mathrm{CH} 4$ and $\mathrm{H} 2$ generation via $\mathrm{CO} 2 / \mathrm{H} 2 \mathrm{O}$ coelectrolysis in eutectic molten salts. Int. J. Hydrogen Energ. 44, 5082-5089. doi: 10.1016/j.ijhydene.2018.09.089

Kacprzak, A. (2019). Hydroxide electrolyte direct carbon fuel cells-Technology review. Int. J. Energ. Res. 43, 65-85. doi: 10.1002/er.4197

Kacprzak, A., Kobylecki, R., and Bis, Z. (2013). Influence of temperature and composition of $\mathrm{NaOH}-\mathrm{KOH}$ and $\mathrm{NaOH}-\mathrm{LiOH}$ electrolytes on the performance of a direct carbon fuel cell. J. Power Sources 239, 409-414. doi: 10.1016/j.jpowsour.2013.03.159

Kacprzak, A., Kobyłecki, R., and Bis, Z. (2016). Effect of fuel pretreatment with HNO3 on operational performance of a direct carbon fuel cell. J. Power Technol. 96, 390-396.

Kacprzak, A., Kobyłecki, R., and Bis, Z. (2017). The effect of coal thermal pretreatment on the electrochemical performance of molten hydroxide direct carbon fuel cell (MH-DCFC). J. Power Technol. 97, 382-387.

Kacprzak, A., Kobyłecki, R., Włodarczyk, R., and Bis, Z. (2014). The effect of fuel type on the performance of a direct carbon fuel cell with molten alkaline electrolyte. J. Power Sources 255, 179-186. doi: 10.1016/j.jpowsour.2014.01.012

Kacprzak, A., and Włodarczyk, R. (2020). Materials selection and construction development for ensuring the availability and durability of the molten hydroxide electrolyte direct carbon fuel cell (MH-MCFC). Materials 13:4659. doi: 10.3390/ma13204659

Lapshin, A. V., Germanskii, A. M., and Bogdanov, S. P. (2004). Interaction of boron nitride with molten sodium hydroxide. Glass. Phys. Chem. 30, 202-206. doi: 10.1023/B:GPAC.0000024007.85239.90

Lee, J., and Holland, G. F. (1991). Identification of a new strontium Ni(III) oxide prepared in molten hydroxides. J. Solid State Chem. 93, 267-271. doi: 10.1016/ 0022-4596(91)90299-W

Li, Z., Yu, Y., Li, W., Wang, G., Peng, L., Li, J., et al. (2018). Carbon dioxide electrolysis and carbon deposition in alkaline-earth-carbonate-included molten salts electrolyzer. New J. Chem. 42, 15663-15670. doi: 10.1039/C8NJ0 2965B

Licht, S., Liu, S., Cui, B., Lau, J., Hu, L., Stuart, J., et al. (2016). Comparison of alternative molten electrolytes for water splitting to generate hydrogen fuel. J. Electrochem. Soc. 163, F1162-F1168. doi: 10.1149/2.0561610jes

Liu, Y., Yuan, D., Ji, D., Li, Z., Zhang, Z., Wang, B., et al. (2017). Syngas production: diverse $\mathrm{H} 2 / \mathrm{CO}$ range by regulating carbonates electrolyte composition from
CO2/H2O via co-electrolysis in eutectic molten salts. RSC Adv. 7, 52414-52422. doi: 10.1039/C7RA07320H

Lu, S. H., and Selman, J. R. (1990). Influence of chemical equilibria on oxygen reduction reaction in molten carbonate. J. Electrochem. Soc. 137, 1125-1130. doi: 10.1149/1.2086614

Lu, S. H., and Selman, J. R. (1992). Electrode kinetics of oxygen reduction on gold in molten carbonate. J. Electroanal. Chem. 333, 257-271. doi: 10.1016/00220728(92)80395-K

Lusiola, T., Bortolani, F., Zhang, Q., and Dorey, R. (2012). Molten hydroxide synthesis as an alternative to molten salt synthesis for producing K0.5Na0.5NbO3 lead free ceramics. J. Mater. Sci. 47, 1938-1942. doi: 10.1007/s10853-011-5984-8

McPhail, S. J., Leto, L., Della Pietra, M., Cigolotti, V., and Moreno, A. (2015). International Status of Molten Carbonate Fuel Cells Technology. ENEA: National Agency for New Technologies, Energy and Sustainable Economic Development. Available online at: http://www.enea.it/it/pubblicazioni/pdfdossier/2015_MCFCinternationalstatus.pdf (accessed 29 April 2016)

Meléndez-Ceballos, A., Gürbüz, E., Brouzgou, A., Albin, V., Ringuedé, A., Lair, V., et al. (2020). Input on the measurement and comprehension of CO2 solubility in molten alkali carbonates in view of its valorization. J. Electrochem. Soc. 167:064504. doi: 10.1149/1945-7111/ab7ce1

Meskine, H., Gürbüz, E., Albin, V., Meléndez-Ceballos, A., Cassir, M., Ringuedé, A., et al. (2020). CO2 electrolysis in a reversible molten carbonate fuel cell: online chromatographic detection of CO. Int. J. Hydrogen Energ. doi: 10.1016/j. ijhydene.2020.08.028 [Epub ahead of print].

Miles, M. H. (2003). Exploration of molten hydroxide electrochemistry for thermal battery applications. J. Appl. Electrochem. 33, 1011-1016. doi: 10.1023/A: 1026270119048

Minakawa, T., Kato, M., Noji, T., and Koike, Y. (2008). Low-temperature synthesis of (Ba, K, Rb)BiO3 using molten hydroxides. Physica $C 468,1132-1134$. doi: 10.1016/j.physc.2008.05.016

Moneuse, C., Cassir, M., Piolet, C., and Devynck, J. (2009). Oxidative coupling of methane in molten barium hydroxide at $800^{\circ}$ C. Appl. Catal. 63, 67-76. doi: 10.1016/S0166-9834(00)81706-6

Mori, H. (2003). Extraction of silicon dioxide from waste colored glasses by alkali fusion using potassium hydroxide. J. Mater. Sci. 38, 3461-3468. doi: 10.1023/A: 1025100901693

Moutiers, G., Cassir, M., and Devynck, J. (1991). Electrochemical characterization of the $\mathrm{O} 2-/ \mathrm{O} 22-$ system in molten $\mathrm{Na} 2 \mathrm{CO} 3,+\mathrm{K} 2 \mathrm{CO} 3$, eutectic at $750^{\circ} \mathrm{C}$. J. Electroanal. Chem. 315, 103-112. doi: 10.1016/0022-0728(91)80063-V

Moutiers, G., Cassir, M., and Devynck, J. (1992). Oxygen reduced species in molten $\mathrm{Li} 2 \mathrm{CO} 3+\mathrm{K} 2 \mathrm{CO} 3(42.7+57.3 \mathrm{~mol} \%)$ at $650^{\circ} \mathrm{C}$. J. Electroanal. Chem. 324, 175-189. doi: 10.1016/0022-0728(92)80044-5

Nishina, T., Ohuchi, S., Yamada, K., and Uchida, I. (1996). Water effect on oxygen reduction in molten (Li+K)CO3 eutectic. J. Electroanal. Chem. 408, 181-187. doi: 10.1016/0022-0728(96)04514-7

Nishina, T., Takahashi, M., and Uchida, I. (1990). Gas electrode reactions in molten carbonate media: IV. Electrode kinetics and mechanism of hydrogen oxidation in (Li+K)CO3 Eutectic. J. Electrochem. Soc. 137, 1112-1121. doi: 10.1149/1. 2086612

Nishina, T., Uchida, I., and Selman, J. R. (1994). Gas electrode reactions in molten carbonate media: V. Electrochemical analysis of the oxygen reduction mechanism at a fully immersed gold electrode. J. Electrochem. Soc. 141, 11911198. doi: 10.1149/1.2054895

Perez-Trujillo, J. P., Elizalde-Blancas, F., Della Pietra, M., and McPhail, S. J. (2018). A numerical and experimental comparison of a single reversible molten carbonate cell operating in fuel cell mode and electrolysis mode. Appl. Energ. 226, 1037-1055. doi: 10.1016/j.apenergy.2018.05.121

Rosen, J., Geary, T., Hilmi, A., Blanco-Gutierrez, R., Yuh, C.-Y., Pereira, C. S., et al. (2020). Molten carbonate fuel cell performance for CO2 capture from natural gas combined cycle flue gas. J. Electrochem. Soc. 167:064505. doi: 10.1149/19457111/ab7a9f

Saïb, N., Claes, P., and Glibert, J. (1998). Chemical and electrochemical behaviour in molten hydroxides. VII. Chromium species in sodium hydroxide. Electrochim. Acta 43, 2089-2100. doi: 10.1016/S0013-4686(97)10118-9

Sang, L., Cai, M., Zhao, Y., Ren, N., Wu, Y., and Burd, C. (2015). Mixed metal carbonates/hydroxides for concentrating solar power analyzed by DSC and XRD. Sol. Energ. Mat. Sol. C. 140, 163-173. doi: 10.1016/j.solmat.2015.04.006 
Sher, F., Al-Shara, N. K., Iqbal, S. Z., Jahan, Z., and Chen, G. Z. (2020). Enhancing hydrogen production from steam electrolysis in molten hydroxides via selection of non-precious metal electrodes. Int. J. Hydrogen Energ. 45, 28260-28271. doi: 10.1016/j.ijhydene.2020.07. 183

Wade, J., Lackner, K., and West, A. (2007). Transport model for a high temperature, mixed conducting CO2 separation membrane. Solid State Ionics 178, 15301540. doi: 10.1016/j.ssi.2007.09.007

Wang, D., Chu, J., Li, J., Qi, T., and Wang, W. (2012). Anti-caking in the production of titanium dioxide using low-grade titanium slag via the $\mathrm{NaOH}$ molten salt method. Powder Technol. 232, 99-105. doi: 10.1016/j.powtec.2012. 07.048

Wang, L., Cai, K. F., Wang, Y. Y., Yin, J. L., Li, H., and Zhou, C. W. (2009). Preparation and characterization of tetragonal-ZrO2 nanopowders by a molten hydroxides method. Ceram. Int. 35, 2499-2501. doi: 10.1016/j.ceramint.2008. 11.034

White, S. H., and Twardoch, U. M. (1984). The electrochemical behaviour of solutions of molten ternary alkali carbonate mixture equilibrated with carbon dioxide-water mixtures at $460{ }^{\circ} \mathrm{C}$. J. Electrochim. Acta 29, 349-359. doi: 10. 1016/0013-4686(84)87074-7

White, S. H., and Twardoch, U. M. (1987). The behavior of water in molten salts. J. Electrochem. Soc. 134, 1080-1088. doi: 10.1149/1.2100620

Williams, D. D., Grand, J. A., and Miller, R. R. (1956). The reactions of molten sodium hydroxide with various metals. J. Am. Chem. Soc. 78, 5150-5155. doi: 10.1021/ja01601a004

Wu, H., Ji, D., Li, L., Yuan, D., Zhu, Y., Wang, B., et al. (2016). A new technology for efficient, high yield carbon dioxide and water transformation to methane by electrolysis in molten salts. Adv. Mater. Technol. 1:1600092. doi: 10.1002/admt. 201600092

Xing, L., Bai, X., Gao, Y., and Cao, Z. (2021). Improving clean electrical power generation: a theoretical modelling analysis of a molten sodium hydroxide direct carbon fuel cell with low pollution. J. Clean. Prod. 281:124623. doi: 10.1016/j.jclepro.2020.124623

Xiong, X., Lei, X., Zhang, C., Wang, J., and Huang, K. (2015). Synergetic proton conduction in $\mathrm{BaZr} 0.8 \mathrm{Y} 0.2 \mathrm{O} 3-\delta$-carbonate composite electrolyte for intermediate-temperature solid oxide fuel cells. Solid State Ionics 279, 66-71. doi: 10.1016/j.ssi.2015.07.008

Xu, M., Wang, F., Zhao, M., Yang, S., and Song, X. (2011). Molten hydroxides synthesis of hierarchical cobalt oxide nanostructure and its application as anode material for lithium ion batteries. Electrochim. Acta 56, 4876-4881. doi: 10. 1016/j.electacta.2011.03.027

Yang, J., Muroyama, H., Matsui, T., and Eguchi, K. (2014). Development of a direct ammonia-fueled molten hydroxide fuel cell. J. Power Sour. 245, 277-282. doi: 10.1016/j.jpowsour.2013.06.143

Zecchin, S., Schiavon, G., and Bombi, G. G. (1974). Interdiffusion coefficient of water in molten hydroxides. J. Electroanal. Chem. 50, 261-267. doi: 10.1016/ S0022-0728(74)80157-9

Zecevic, S., Patton, E. M., and Parhami, P. (2004). "Direct carbon fuel cell with molten hydroxide electrolyte," in Proceedings of the 2nd International Conference on Fuel Cell Science, Engineering and Technology, (Rochester, NY: Fuel Cell Science), 387-394. doi: 10.1115/FUELCELL2004-2496

Conflict of Interest: The authors declare that the research was conducted in the absence of any commercial or financial relationships that could be construed as a potential conflict of interest.

Copyright (c) 2021 Gürbüz, Grépin, Ringuedé, Lair and Cassir. This is an open-access article distributed under the terms of the Creative Commons Attribution License (CC BY). The use, distribution or reproduction in other forums is permitted, provided the original author(s) and the copyright owner(s) are credited and that the original publication in this journal is cited, in accordance with accepted academic practice. No use, distribution or reproduction is permitted which does not comply with these terms. 